\title{
Coal Tar Production Processes and Potential of PAHs Release into the Environment
}

\author{
E. Fosso-Kankeu
}

\begin{abstract}
Coal has been mainly used in South Africa for electricity generation by the power utility, however, with the rapid decline of high grade coal, other processes such as gasification and coal coking which rely mostly on low grade coal are likely to be the main consumers of coal in a foreseeable future. Such processes produce significant amount of coal tars which are often recycle in the system, but an excess of tars are often discharged in the environment. Coal tar contains a variety of polycyclic aromatic hydrocarbons (PAHs) at relatively high concentrations. PAHs are known to be toxic to human and other form of biological systems, and could therefore pose significant health issues if not properly handled or released in environmental ecosystems such as water.
\end{abstract}

Keywords - Coal tar, gasification, coal coking, PAHs.

\section{INTRODUCTION}

Most of the PAHs released from their sources are discharged into the atmosphere [1]. Human activities release more PAHs than natural sources, mostly through the burning of coal, common fuels and other organic materials [2,3]. The burning of wood was found to be the largest source of atmospheric PAHs [4]. The largest natural sources of PAHs include volcanoes and forest fires. Approximately 75 percent of total PAH emissions are from stationery sources, such as production of coke, coal tar, power generation, etc. The remaining 20 percent of $\mathrm{PAH}$ emissions is from diesel vehicles and mobile sources. The composition of PAH emissions differ significantly depending on the source [4,5]. The deposition of airborne PAHs from burning sources was reported to be the largest source of PAHs in soil and surface water $[4,6]$. Nevertheless, in local environments the higher concentrations of PAHs may come from runoff in car parking areas and sealed roads [6]. PAHs are also found in materials associated with roads and parking lots, including tyre dust, brake lining particles, and used and new motor oil [5]. However, attention will be focused on the coal processing through gasification and coking as well as combustion of tar as sources of PAHs.

\section{IMPORTANCE OF COAL AS ENERGY SOURCE IN SA}

Globally, coal plays an important role in securing energy demand and is expected to remain the second largest primary fuel source until 2030 [7,8]. As from 2008, the global coal reserve was estimated to be around 861 billion tonnes,

Manuscript received August 20, 2017. This work was supported in part by the North-West University.

E. Fosso-Kankeu is with the School of Chemical and Minerals Engineering at the North-West University, Potchefstroom, South Africa. however, coal of high quality is rapidly depleting because of the increasing demand, especially from the biggest consumers such as China and the USA [9].

With a coal reserve estimated at $31 \mathrm{Gt}$ in 2006 according to the South African Year Book 2007/2008, South Africa is ranked as eighth in the world [10]. As far as coal reserve in the African continent is concerned, the major stake belongs to South Africa with approximately $75 \%$ of the African coal resources [11,12]. As from 1999 the bulk of mineable reserves were contained in the Ermelo, Witbank, Highveld and Sasolburg-Vereeniging coalfields which are close to major South African industrial centres [13]. The Ellisras basin including the Waterberg Coalfield is estimated to contain more than $50 \%$ of South Africa's remaining coal reserve; however, because of some geological structural disturbances, a proper geophysical survey is required prior to the exploitation of this immense reserve [14].

South Africa mines around $220 \mathrm{Mt}$ of coal per annum and is considered as the $6^{\text {th }}$ largest producer in the world, behind countries like China and the USA. Coal mines or collieries are the major suppliers of coal through companies such as Sasol, Exxaro, Anglo American Thermal Coal, BHP Billiton Energy Coal South Africa and Glencore Xstrata, which export high-grade coal to developed countries, while local energy and petro-chemical industries rely mostly on low-grade coal as feedstock [15]. According to a report by Hancox and Gotz in 2014, the main coalfields of South Africa include: Witbank Coalfield, Highveld Coalfield, Ermelo Coalfield, Coalfields in the Free State (Vereeniging-Sasolburg Coalfield, Free State Coalfield and South Rand Coalfield), Coalfields in KwaZulu-Natal (Klip River Coalfield, Utrecht Coalfield, Vryheid Coalfield, Nongoma Coalfield, Somkhele Coalfield), Kangwane Coalfield, Springbok Flats Coalfield, Waterberg Coalfield, Soutpansberg Coalfield, Limpopo Coalfield and Molteno Coalfield. The Witbank Coalfield supplies more than $50 \%$ of South Africa's saleable coal; the highveld coal field located in the Mpumalanga Province of South Africa in the South of the Witbank Coal field, is the second largest in term of production among the nine currently producing coal field and the nineteen existing Coal field in South Africa $[12,16]$.

Coal is the major source of energy in South Africa, accounting for $72 \%$ of total primary energy supply in the country in 2005 , while contributing to approximately $95 \%$ of the electricity generated. It is reported that South African coal is also used domestically as a feedstock for the production of considerable amount of the country's liquid fuels [17]; the South African Synthetic Oil Limited (Sasol) is reported as the fastest growing consumer of coal, using $29 \%$ of the locally 
produced coal to feed the gasifiers of the Sasol Chemical Industries (SCI) at Sasolburg and Sasol Synthetic Fuels (SSF) at Secunda for conversion into crude synthesis gas $[17,18]$. According to current practices, more than half of our mined coal considered as low-grade coal is used by the electricity and petro-chemical industries; the latter relying on gasification processes to produce fuel and synthetic chemicals. However, with rapidly growing consumption of coal (researchers forecast that the extreme reliance of the country on coal for power generation and electricity supply, will result to a peak in production rate of about $284 \mathrm{Mt} /$ year in 2020 , contributing to the exhaustion of at least half $(12 \mathrm{Gt})$ of the total reserve $(23 \mathrm{Gt})$ which will compel consumers to mostly depend on or develop processes suitable for low-grade coal [19]); it is for example estimated that processes such as underground coal gasification (UCG) may eventually make marginal coal reserves accessible [20]. The major environmental problem associated with such processes is the coal tar generated as bioproduct which may be challenging to handle and has potential to release carcinogenic compounds such as polycyclic aromatic hydrocarbons (PAHs) in the receiving waters.

\section{COAL PROCESSES LIKELY TO PRODUCE TARS}

The rapid decline of quality coal is likely to contribute to increase use of technologies which can be effectively operated with low quality coal such as gasification for the production of energy, chemicals and other products. These technologies are more prone to the generation of tar as by-product. The description of the processes involved in these technologies will be considered in this section allowing to identify the steps involved in tar production.

\section{A. Gasification processes}

The main gasification processes involve the reaction of coal with steam and oxygen to produce a combustible gas or a synthesis gas which may include carbon dioxide, carbon monoxide, hydrogen, water vapour and methane which can be further used for clean power and chemicals production. Two main industrial processes can be delineated on this basis, namely the Sasol-Lurgi gasification process and the underground coal gasification.

\section{B. Sasol-Lurgi gasification process}

The South Africa Synthetic Oil Liquid (Sasol) industry was created in 1950 as the South African government decided to find alternative to imported oil by making liquid fuel from coal via gasification and subsequent liquefaction of the resulting fuel gas [21]. The Sasol-Lurgi gasification process was developed in Germany during the 1930's and uses coal (mainly butimunous coal) as main feedstock in a fixed bed dry bottom gasification process at high temperature and pressure in the presence of steam and oxygen to produce synthesis gas which is converted to fuels and chemicals via the Fischer-Tropsch process (Figure 1).

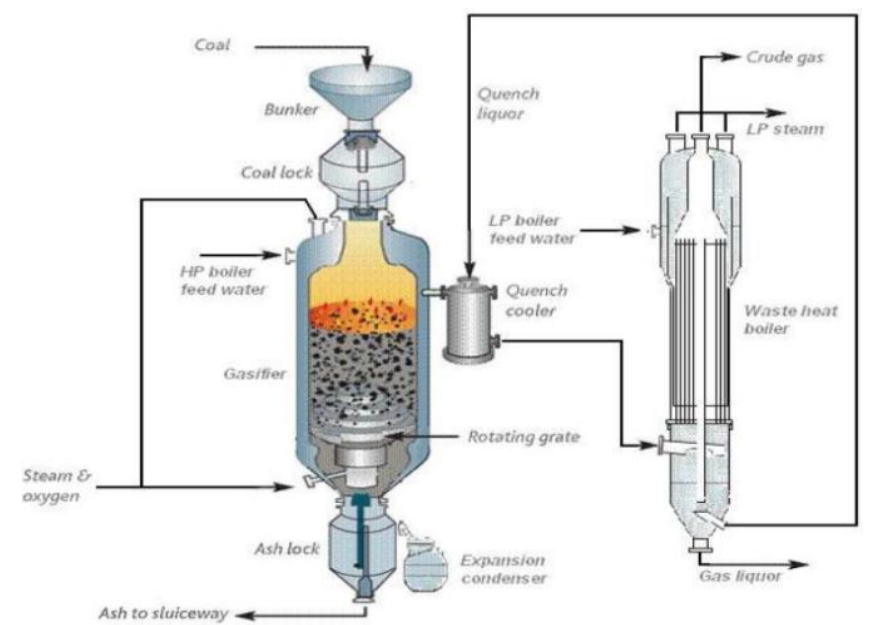

Fig. 1 Sasol's gasifier unit [79]

The Sasol gasifiers are very tolerant to changes in feedstock quality, capable to gasify coal with ash content as high as $35 \%$ [23]; it is estimated that $>30$ million tons per annum of bituminous coal of the domestically produced coal is consumed by Sasol in the gasification process. During raw gas cooling, unreacted gasification steam and water formed in some of the gasification reactions condense, these wastewater streams contain a number of contaminants including tar, oil and phenols (Figure 2) that must be removed prior to reuse and discharge. Although wastewaters generated from the Fischer-Tropsch process are treated through the biological oxidation (Figure 2) coupled with ash-handling for polishing of residual organics, the solid wastes are often not properly disposed of. These wastes include gasifier ash, boiler fly and bottom ash, and dusty tar. The ash is often disposed in a surface dump without any further measure to prevent leachates from entering the groundwater, while the dusty tar is disposed of by landfilling [24].

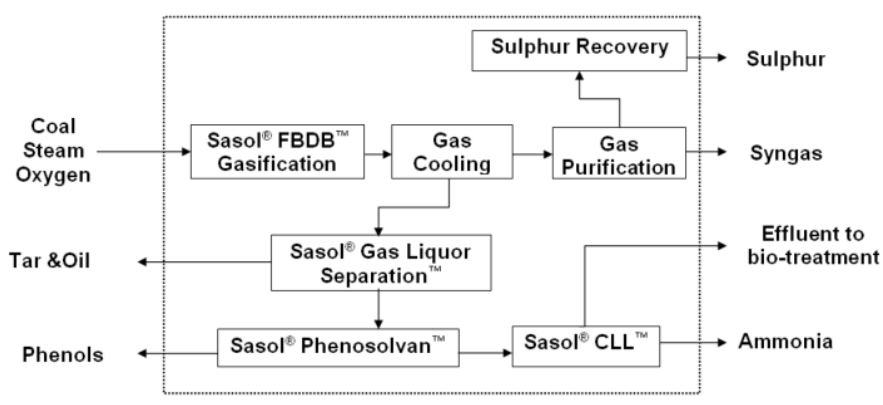

Fig. 2 Syngas production block flow diagram [23]

\section{Underground Coal Gasification}

The decrease of high quality coal coupled to challenges associated with conventional mining process such as high cost associated with the exploitation of deep coal deposits, pollution pertaining to increasing dust and noise production, disposal of ash and coal tailings in the environment and methane emission to the atmosphere have promoted increasing interest to underground coal gasification (UCG) [24-27]. Gasification refers to an incomplete burning of coal [28,29]; basically, UCG mainly consists of the injection of air, oxygen, steam or any combination of these underground to sustain fire from ignited coal to produce a combustible 
synthetic gas (Figures 3 and 4) which can be used for industrial heating, power generation or the manufacture of synthetic gas or diesel fuel [30]. Currently, the extraction of coal by the underground coal gasification technique appears to be both economically and technically feasible [28]. UCG makes possible the exploitation of marginal coal reserves that could not be recover using the conventional method therefore offering the prospect of increasing the world's usable coal reserves by a factor of no less than three. Inaccessible and low grade coal can be competitively converted by UCG to syngas that will be eventually used for power generation and production of chemicals [30]. UCG started in the former Soviet Union in the 1930s where an experimental station was established in the Donetsk coalfield; a commercial installation only followed in 1940 in the same country. Up to today a number of UCG operations have been reported in Majuba-South Africa, Queensland-Australia, Alberta-Canada, Walanchabi City-China and Angren-Uzbekistan. UCG syngas has been produced at Majuba in South Africa since 2007, the project is considered as the longest UCG running trial in the western world contributing about $3 \mathrm{MW}$ to the overall output of $650 \mathrm{MW}$ at the Majuba Power Station. The facilities are to be expended in the near future to an output of $1200 \mathrm{MW}$, the syngas will contribute to around $30 \%$ of the plant fuel [30].

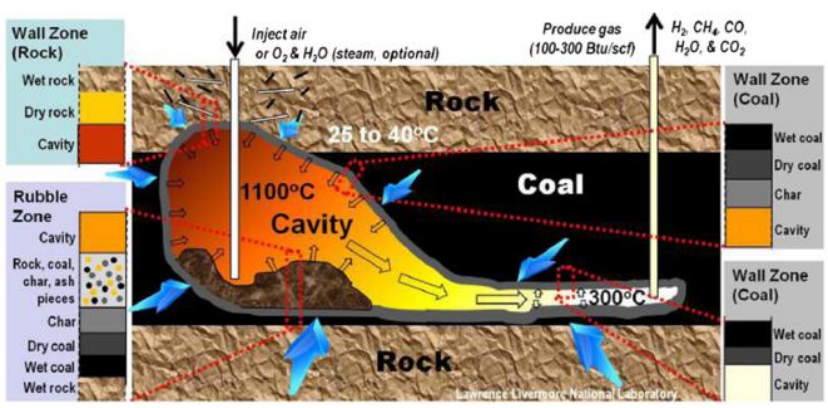

Fig. 3Typical cavity configuration of a mid-to-late stage of a linked vertical well module [30].

The reduced emission of toxic gases as well as discharged of solid wastes in the environment makes UCG environmental safer compared to the conventional processes. However, studies carried out on groundwater pollution from UCG since the initiation of large scale research on UCG in Soviet Union at the beginning of the previous century, have shown that a wide range of hazardous species which are by-products of the gasification and pyrolysis processes are released in the underground environment. During pyrolysis, zones of reduction and oxidation are created as a result of the long gasification of sections. In such conditions a number of organic pollutants are produced. Krzysztof and Krzysztof conducted a study of the pollution of water during the process of UCG [31]. Typical pollutants identified in groundwater nearby UCG process include phenols, benzene and its derivatives, polycyclic aromatic hydrocarbons (PAHs), heterocyclics and inorganic pollutants, mainly sulphate, chloride and ammonium [32-36]. It is suggested that the source of organic pollutants and ammonia is mainly condensed vapors, while the inorganic pollutants derived primarily from ash leachates [35].

\section{Coking of coal}

Coke acts as reducing agent in furnaces smelting iron ore to produce liquid iron which is an essential ingredient in the steel manufacturing, the core business of ArcelorMittal South Africa. Coke is the material left when water, coal-gas and coal-tar are driven off during the carbonization of coal at temperatures around $1100{ }^{\circ} \mathrm{C}$ in an air-tight oven, a process refers as cokemaking or coking [37]. The coking process often takes place in a coke battery in which coal is loaded; this battery is composed of many coke ovens stacked in rows and often located at or near an integrated steel mill. To produce metallurgical coke for the blast furnace on site, ArcelorMittal South Africa operates five coke batteries, during this process gas and other by-products including tar are formed (Figure 4). It is estimated that around 109000 tonnes of tar was produced in 2013, this creates an environmental concern as a total of $1.65 \mathrm{~m}$ tonnes of by-products produced in the same period needed space to be disposed of with 290 ha of land under restoration [38]. Apart from solid wastes, a polluted wastewater effluent is also generated from coal coking, coal gas purification and by-product recovery processes of coke making factories in the iron-steel-producing industries. This wastewater is rich in organic and inorganic matters, and generally challenging to treat through biological method because of its complexity and high toxicity [39-41].

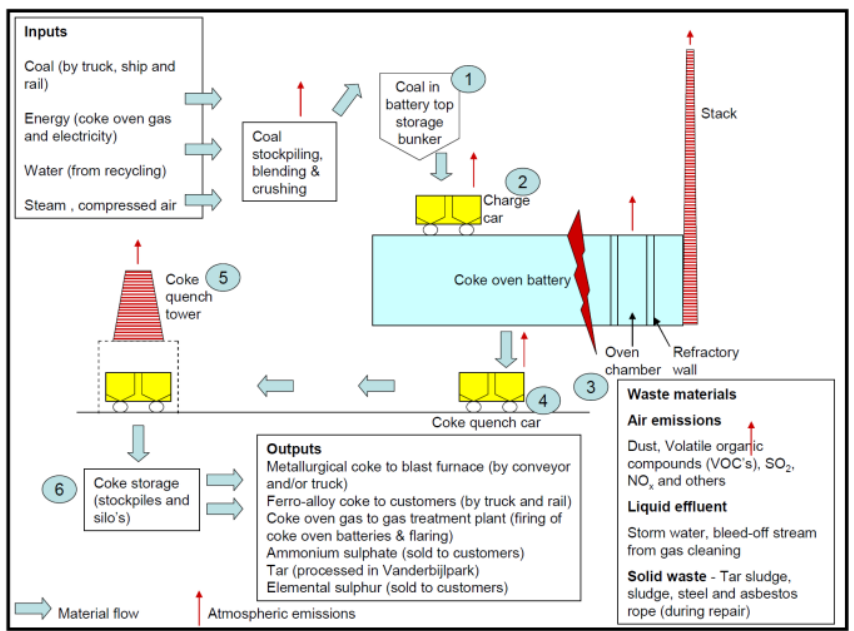

Fig. 4 Schematic diagram of the coke production process, indicating inputs, outputs and waste materials [38]

\section{E. Domestic combustion of Tar}

Heating and cooking are the domestic sources of PAHs which can influence the quality of water. The use of natural gas, heating oil, wood, and coal differs from the domestic heating based on combustion of fuels [42]. The PAHs emission from domestic sources is found to be largely unregulated [42]. Such activities generally have high PAH emissions. Benzopyrene from the burning of wood and peat is reported to be associated with a range of particle sizes [1]. Internal combustion engines of motor vehicles are generally supported by diesel and petrol fuels. The air-to-fuel ratio is reported to be the major factor influencing PAHs production. Bjorseth [42] and Ravindra et al. [1] also found that the 
reduction of the PAHs concentration in the exhaust gases can be influenced by the use of catalytic converters. The PAHs' emission characteristics of all internal combustion engines are different due to engine temperature, load, speed and fuel quality. Petrol fueled vehicles have lower emission compared to diesel-fueled vehicles $[43,44]$.

\section{F. Leaching of Tar to Water}

Wastewater discharged from preserving facilities is the main source of creosote released into waters. In previous years, the water from wood-preserving facilities was often discharged to settling basins where a sludge formed [45]. The creosote components filtered through the soil to reach the groundwater table. Water-soluble creosote constituents can be leached from marine pilings and treated wood products to surface waters and groundwater [45,46].

\section{CONCLUSION}

Millions of tons of coal tar are discharged in the environment throughout the world every year without proper management; the risks of PAHs release from such coal tar and the potential impact on the environment has often been overlooked, while the deleterious effects continue to cause a lot of health issues among humans and other biological systems. It is therefore important for future research to focus on the environmental risks related to coal tar.

\section{ACKNOWLEDGMENT}

The author is grateful to the financial support from Water Research Commission of South Africa (WRC, Project No 2974).

\section{REFERENCES}

[1] Ravindra, K., Sokhi, R., and Van Grieken, R., Atmospheric polycyclic aromatic hydrocarbons: source attribution, emission factors and regulation. Atmospheric Environment, 42(13), 2895-2921, 2008. https://doi.org/10.1016/j.atmosenv.2007.12.010

[2] Soclo, H., Garrigues, P., and Ewald, M., Origin of polycyclic aromatic hydrocarbons (PAHs) in coastal marine sediments: case studies in Cotonou (Benin) and Aquitaine (France) areas. Marine pollution bulletin, 40(5), 387-396, 2000.

https://doi.org/10.1016/S0025-326X(99)00200-3

[3] Li, G., Xia, X., Yang, Z., Wang, R., and Voulvoulis, N., Distribution and sources of polycyclic aromatic hydrocarbons in the middle and lower reaches of the Yellow River, China. Environmental pollution, 144(3), 985-993, 2006. https://doi.org/10.1016/j.envpol.2006.01.047

[4] Agency for Toxic Substances and Disease Registry, Toxicological profile for polycyclic aromatic hydrocarbons. US Department of Health and Human Services, 1995.

[5] Edokpayi, J.N., Odiyo, J.O., Popoola, O.E., Msagati, T.A.M., Determination and distribution of polycyclic aromatic hydrocarbons in rivers, sediments and wastewater effluents in Vhembe district, South Africa. Int. J. Environ. Res. Public Health, 13(4), 387-398, 2016. https://doi.org/10.3390/ijerph13040387

[6] Nekhavhambe, T.J., Van Ree, T., and Fatoki, O.S., Determination and distribution of polycyclic aromatic hydrocarbons in rivers, surface runoff, and sediments in and around Thohoyandou, Limpopo Province, South Africa. Water SA, 40(3), 415-424, 2014. https://doi.org/10.4314/wsa.v40i3.4

[7] Shafiee, S., Topal, E., An econometric view of worldwide fossil fuel consumption and the role of US. Energy Policy, 36, 775-786, 2008. https://doi.org/10.1016/j.enpol.2007.11.002

[8] Wolde-Rufael, Y., Coal consumption and economic growth revisited, Applied Energy, 87, 160-167, 2010. https://doi.org/10.1016/j.apenergy.2009.05.001

[9] World Energy Council, Survey of Energy Resources, 2010. available at http://go.nature. com/hde5r7.
[10] Government Communication and Information System (GCIS), Minerals, energy and geology. In: Burger D, editor. South Africa Yearbook 2007/08. Pretoria: GCIS, 2008; 397-426. Available from: http://www.gcis.gov.za/resource_centre/sa_info /yearbook/2007-08.htm.

[11] Snyman, C.P. and Botha, W.J., Coal in South Africa, Journal of African Earth Sciences (and the Middle East, 16(1-2), 171-180, 1993. https://doi.org/10.1016/0899-5362(93)90165-M

[12] Wagner, N.J., Hlatshwayo, B., The occurrence of potentially hazardous trace elements in five Highveld coals, South Africa, Int. J. Coal Geol., 63, 228-246, 2005. https://doi.org/10.1016/j.coal.2005.02.014

[13] Rogers, M.H., Presidential Address: Coal - An industry in change, The Journal of South African Institute for Mining and Metallurgy, SA ISSN 0038-223X/3.00 + 0.00, 227-242, 1999.

[14] Fourie, C.J.S., Du Plessis, S.J., Heruy, G., New airbone geophysical data from the Waterberg coalfield: South Africa's major future energy source. Paper presented at: Science real and relevant. Proceedings of the $2^{\text {nd }}$ CSIR Biennial Conferences; 2008 Nov 17-18; Pretoria, South Africa. Available from http://researchspace.csir.co.za/dspace/bitstream/10204/2568/1/Fourie 2008.pdf.

[15] Mangena, S.J. and Brent, A.C., Application of a life cycle impact assessment framework to evaluate and compare environmental performances with economic values of supplied coal products, Journal of Cleaner Production, 14, 1071-1084. https://doi.org/10.1016/j.jclepro.2004.04.012

[16] Jordaan, J., Highveld Coalfield. In: Anhaeusser, C.R., Maske, S. (Eds.), Mineral Deposits of Southern Africa, vol. II. Geological Society of South Africa, Johannesburg, 1985-1994, 1986

[17] Hancox, P.J. and Gotz, A.E., South Africa's coalfields - A 2014 perspective, International Journal of Coal Geology, 132, 170-254, 2014. https://doi.org/10.1016/j.coal.2014.06.019

[18] Blignaut, J.N. and Hassan, R.M., Assessment of the performance and sustainability of mining sub-soil assets for economic development in South Africa, Ecological Economics, 40, 89-101, 2002. https://doi.org/10.1016/S0921-8009(01)00267-1

[19] Hartnady, C.J.H., South Africa's diminishing coal reserves, South African Journal of Science, 106(9/10), 369-374. https://doi.org/10.4102/sajs.v106i9/10.369

[20] Heinberg, R. and Fridley, D., The end of cheap coal, Nature, 468, 367-369, 2010. https://doi.org/10.1038/468367a

[21] Minchener, A.J., Coal gasification for advanced power generation, Fuel, 84, 2222-2235, 2005. https://doi.org/10.1016/j.fuel.2005.08.035

[22] Van Dyk, J.C., Keyser, M.J., Coertzen, M., Syngas production from South African coal sources using Sasol-Lurgi gasifiers, International Journal of Coal Geology, 65, 243-253, 2006 https://doi.org/10.1016/j.coal.2005.05.007

[23] Quass, J.D. and Skinner, F.D., Process description of the Sasol I coal gasification plant: Topical report. Gas Research Institute, Environment and Safety Research, Chicago, USA, 1987

[24] Green, M., UK programme on underground coal gasification, R-250, DTI, 2000

[25] Walker, L.K., Blinderman, M.S., Brun, K., An IGCC Project at Chinchilla, Australia based on underground coal gasification. In: 2001 gasification technologies conference, San Francisco, 8 - 10, 2001.

[26] Beath, A., Process studies for clean electricity and liquid fuels from UCG. In: International Workshop on Underground Coal Gasification, DTI Conference Centre, London, 1-2 October 2003.

[27] Khadse, A., Qayyumi, M., Mahajani, S., Aghalayam, P., Underground coal gasification: A new clean coal utilization technique for India, Energy, 32, 2061-2071, 2007 https://doi.org/10.1016/j.energy.2007.04.012

[28] Walker, L., Underground coal gasification: a clean coal technology ready for development, Australian Coal Review, 19-21, 1999.

[29] David, B., Brian, T., Maohong, Coal gasification and its application. Applied sciences, 35-72, 2011. https://doi.org/10.1016/B978-0-8155-2049-8.10003-8

[30] Bhutto, A.W., Bazmi, A.A., Zahedi, G., Underground coal gasification: From fundamentals to applications, Progress in Energy and Combustion Science, 39, 189 - 214, 2013. https://doi.org/10.1016/j.pecs.2012.09.004

[31] Kapusta, K., and Stanczyk, K., Pollution of water during underground coal gasification of hard coal and lignite. Fuel, 90, 1927-1934, 2011. https://doi.org/10.1016/j.fuel.2010.11.025 
[32] Stuermer, D.H., Ng, D.J., Morris, C.J., Organic contaminants in groundwater near an underground coal gasification site in northeastern Wyoming, Environ. Sci. Technol., 16, 582 - 587, 1982. https://doi.org/10.1021/es00103a009

[33] Lindblom, S.R., Smith, V.E., Rocky Mountain 1 underground coal gasification test Hanna, Wyoming. Groundwater evaluation. Final Report. US DOE. DOE/MC/25038-3652, 1993.

[34] Covell, J.R., Thomas, M.H., Combined air sparge and bioremediation of an underground coal gasification site. US DOE. DOE/MC/31346-97/C0830, 1996.

[35] Shu-qin, L., Jing-gang, L.I., Mei, M., Dong-lin, D., Groundwater pollution from underground coal gasification, Journal of China University of Mining and Technology, 17(4), 467-472, 2007. https://doi.org/10.1016/S1006-1266(07)60127-8

[36] Kapusta, K. and Stanczyk, K., Pollution of water during underground coal gasification of hard coal and lignite, Fuel, 90, 1927-1934, 2011. https://doi.org/10.1016/j.fuel.2010.11.025

[37] Bieda, B., Grzesik, K., Sala, D. and Gawel, B., Life cycle inventory processes of the integrated steel plant (ISP) in Krakow, Poland - coke production, a case study, International Journal of Life Cycle Assess, DOI 10.1007/s11367-015-0904-9, 2015.

[38] ArcelorMittal South Africa, Parliament colloquium on beneficiation, 24 August 2014, 2014. https://www.thedti.gov.za/parliament/2014/ArcelorMittal.pdf. Accessed 15 June 2019.

[39] Zhang, M., Tay, J.H., Qian, Y., Gu, X.S., Coke plant wastewater treatment by fixed biofilm system for COD and HN3-N removal, Water. Res., 32, 519-527, 1998. https://doi.org/10.1016/S0043-1354(97)00231-5

[40] Kim, Y.M., Park, D., Jeon, C.O., Lee, D.S., Park, J.M., Effect of HRT on the biological pre-denitrification process for simultaneous removal of toxic pollutants from cokes wastewater, Bioresour. Technol., 99, 8824-8832, 2008

https://doi.org/10.1016/j.biortech.2008.04.050
[41] Zhou, X., Li, Y., Zhaob, Y., Yueb, X., Pilot-scale anaerobic/anoxic/oxic/oxic biofilm process treating coking wastewater. Wiley Online Libr. DOI: 10.1002/jctb.3832, 2012.

[42] Bjorseth, A., Lunde, G., Lindskog, A., A long-range transport of PAHs. Atmos. Envir., 2, 45-53, 1979. https://doi.org/10.1016/0004-6981(79)90243-9

[43] Elvis Fosso-Kankeu. 2019. Nano and Bio-based Technologies for wastewater treatment: Prediction and Control Tools for the dispersion of Pollutants in the Environment. Wiley Scrivener. ISBN: 978-1-119-57709-6. Pp 301-336.

[44] N. Mukwevho, E. Fosso-Kankeu, F. Waanders. 2019. PAHs Released from Coal Tars and Potential Removal Using Nanocatalysts. In Nano and Bio-based Technologies for wastewater treatment: Prediction and Control Tools for the dispersion of Pollutants in the Environment Editor: Elvis Fosso-Kankeu. Wiley Scrivener. ISBN 978-1-119-57709-6. Pp 169-203. https://doi.org/10.1002/9781119577119.ch6

[45] Hickok, E.A., Erdmann, J.B., Simonett, M.J., Boyer, G.W., Johnson, L.L., Groundwater contamination with Creosote Wastes: ASCE Environmental Engineering Division Speciality Conference Proceedings, 1982.

[46] US Department of Agriculture, The biological and economic assessment of pentachlorophenol, inorganic arsenicals, creosote, v.1, wood preservatives: Technical Bulletin No. 1658-1, 435, 1980.

The corresponding author is currently an Associate Professor in the School of Chemical and Minerals Engineering at the North-West University (Potchefstroom). He is an NRF rated researcher who has published journal articles, book chapters and books.

Prof Elvis Fosso-Kankeu has been the recipient of several merit awards. 